Laser and Electron-Beam Interactions with Solids Grain Boundaries in Semiconductors Scientific Basis for Thin Films and Interfaces Nuclear Waste Management Metastable Materials Formation Ion Implantation Rapidly Solidified Amorphous and Crystalline Alloys Materials Processing in the Reduced Gravity Environment of Space Application of Synchrotron Radiation to Materials Sci Microscopy and Chemical Analysis of Segregation and Clustering in Crystalline Solids Polymers as Electronic Materials Solit Stra Information Storage Effects of Flyash Incorporation in cement and concrete Modeling and Theory-Driven Design of Polymers Advances in Mechanics of Biological and Bioinspired Materials Engineering and Application of Bioinspired Synthetic Tools for Understanding Biological Phenomena Integration of Biomaterials with Organic Electronics Advan Study and Treatment of Cancer Materials for Neural Interfaces Micro- and Nanoscale Processing, of Materials for Bi Performance Large-Area Processing and Patterning for Active Optical and Electronic Devices Inorganic and Hybrid Materials for Electronics and Photonics Emergent Electron Transpo Oxide Semiconductors Diamond Electronics and Biotechnology-Fundamentals to Applicati Phenomena in Functional Materials Enabling Metamaterials-From Science to Innovation Hybrid Organic-Inorganic Solar Cells Sustainable Solar Energy Conversion Using Earth-Abu Science to Applications Advanced Materials for Rechargeable Batteries Materials an Energy Materials In-Situ and Operando Surface/Interface Characterization and Rene Solid Stater 目 and-Click Synthesis-implementations of Click Chemistm E晋 E旦目 Structures for Tissue Engineering Multiscale Materials in LE 30

\title{
years of MRS Meetings
}

$\mathbf{M}$ y first Materials Research Society (MRS) Meeting was the Fall Meeting of 1981. The Meeting was held in the Boston Park Plaza Hotel. The Meeting only had a small fraction of the symposia of today's Meetings, but it was very exciting. The symposia of interest to me focused on beam processing of materials. Pulsed laser annealing was very hot at that time. (Pun fully intended!) Ideas about nonthermal processes in pulsed laser annealing had been put forth, aggressively disputed, battle lines were drawn, and the contest was on! One of my colleagues told me about the MRS, and he and I performed some work and put together an abstract, which was accepted as a poster paper. At the Meeting, I remember vigorous debates/discussions/arguments that occurred both within and outside of the session rooms. The poster sessions at the Park Plaza were in a fairly confined space, compared to today's sessions. There were wall-to-wall people for hours. People ignored the time limits, with discussions (and beer) continuing into the wee hours of the morning. I had registered and arranged for lodging late, so I was unable to get into the Park Plaza Hotel, or even anything close to it. I was able to get a room at the Lenox, which is close to the Hynes Convention Center, but this meant slogging to and from the Park Plaza every day, often well after midnight for the return to the Lenox. At the time, this didn't bother me the way it would today.

The controversy over pulsed laser annealing and its mechanisms continued for several years, until most of the adherents of nonthermal models finally conceded that pulsed laser annealing could be explained quite well with strictly thermal models (although there may still be some wiggle room for femtosecond laser pulses). The controversy and the associated debates were intellectually stimulating. Some of the nonthermal models were quite elegant, but over time were ruled out by experimental evidence. As a young researcher, I was impressed by the intellectual horsepower displayed on all sides of the debate, the rigor that was applied by many of those involved, and the intellectual agility shown in coming up with new hypotheses as well as experimental approaches to test the hypotheses. Lest you think me high on caffeine or befuddled with memory loss, I also must acknowledge that some sloppy work was performed and presented that confused the discussion somewhat. Nonetheless, the Meeting process helped to separate the chaff from the wheat in a highly effective manner.

A few years later the Fall Meeting moved to the Boston Marriott at Copley Place, which was roomier and was connected to the restaurants and shops of Copley Place. This move was necessary because of the expansion of the number of symposia, and the corresponding increase in attendance. The Fall Meeting gradually expanded to take in rooms at the Westin and also at the Sheraton. The three hotels are connected together by the Copley Place complex, so that one can easily move between the sites. However, the walk from the Marriott to either other hotel would typically result in missing one talk, unless it happened during one of the breaks. And God help you if you wanted to go from a talk in the Sheraton to a talk in the Westin. It might take you two-to-three talks just to recover from the trek. Nonetheless, the walkways through Copley Place were crowded with colleagues, and most seemed only too happy to engage in impromptu side meetings in transit (with anyone!). On the other hand, for some of my colleagues this may have been their only significant aerobic exercise in a given year, so it may have had some small health benefits.

I missed the early sessions on high-temperature superconductors. I couldn't get into the session rooms, or even close for the invited talks. The overflow pushed well out into the corridors. However, most of the time the Meeting Organizers do a pretty good job now of estimating likely attendance and selecting the appropriate rooms. 
Of course, there are events for which no planner can be held accountable. In the spring of 1992, following the acquittal of the officers involved in the Rodney King incident, many cities erupted in riots. This verdict vindicated police officers of racial profiling and brutality that polarized the country and led to riots in several US cities, including San Francisco. I was strolling through Union Square in San Francisco on my way to the Meeting with a colleague during the Spring Meeting that year, when the riots in San Francisco began. We saw crowds breaking out windows, fires started on the streets, overhead awnings broken down, barricades erected by the rioters, and the police response. We hurried through that to get back to the Meeting location at the San Francisco Marriott before things broke down completely. The Marriott had brought in extra staff and had guards at all of the entrances, so our Meeting went on. At the end of that day's poster session, I came up from the underground part of the Marriott to return to my hotel on Union Square only to find that we were 10 minutes away from an area-wide curfew, and people were trying to persuade us not to leave the hotel. A few of us determined that we needed to get to our hotels and talked an intrepid cabbie into taking us. I remember the wild ride and having to knock on the front door of my hotel (off of Union Square) to get someone to unlock the door and let me in. Regardless of all this, the Meeting continued and was completed successfully.

Now the Fall Meetings have mostly moved into the Hynes Convention Center (with a few symposia in hotels). The 2012 Fall Meeting had 53 symposia. The Spring Meetings have expanded from the Marriott into the Moscone Center. The 2013 Spring Meeting had 57 symposia. It now takes three letters to enumerate the symposia (A to EEE). The coverage of materials research of both Meetings is broad enough to provide a home for most people involved in materials research. These Meetings have provided a home for me for more than 30 years. I've made lasting friendships with colleagues from academia, industry, national laboratories, and MRS staff. The presentations in sessions as well as discussions in side meetings have filled my plate with ideas for research every time I've attended a Meeting, some of which I've brought back to MRS Meetings in the form of presentations and publications. As a manager, I've found high-quality candidates for jobs with my organization and have hired several of them to work for my company. I eagerly attend the Exhibit Hall at every Meeting to talk to vendors and catch up on advances in materials and instrumentation (and also to get hugs from MRS staffers). Those discussions with vendors have frequently resulted in purchases of instrumentation crucial to my work or that of my staff. I've presented oral and poster papers at a number of Meetings, and have helped to organize a symposium. Because of my long involvement, I have been invited to participate in MRS committees and have made lasting friendships through that process. Among other things, I've served on the Editorial Board of MRS Bulletin and served as a Volume Organizer for the Bulletin in 2012.

Little did I know when I attended my first MRS Meeting back in the fall of 1981, the long-term impact that MRS Meetings would have on my career. Attendance at Meetings has significantly helped me both as a researcher and as a manager. Over that time, the Society has gone through many changes, including changes in member demographics (industrial versus academic), philosophical debates about whether MRS was a scholarly society or a meetings society (we seem to be both), the growth of international membership, and the transition from print to electronic publication processes, for example. Throughout all of this MRS has remained the premier society for materials research. In closing, I acknowledge that I am an unabashed cheerleader for MRS and encourage all materials researchers to avail themselves of the opportunities inherent in MRS membership, attendance at MRS Meetings, and participation in MRS committee activities.

Steven C. Moss 